\title{
Study Factors Affecting the Level of Information Disclosure of Vietnamese Enterprises
}

\author{
Dang Ngoc Hung (Corresponding author) \\ Faculty of Accounting \& Auditing \\ Hanoi University of Industry, 298 Cau Dien \\ Bac Tu Liem District, Ha Noi, Vietnam \\ E-mail: hungdangngockt@yahoo.com.vn
}

Pham Thi Hong Diep

Faculty of Accounting \& Auditing

Hanoi University of Industry, Vietnam

\section{Dang Thai Binh}

Vietnam Institute for Indian and Southwest Asian Studies

Vietnam Academy of Social Sciences, Vietnam

Received: April 15, 2019

doi:10.5296/ijafr.v9i2.14662
Accepted: May 1, 2019

Published: May 7, 2019

URL: https://doi.org/10.5296/ijafr.v9i2.14662

\begin{abstract}
This study explores the status of information disclosure and the factors affecting the disclosure of information in the annual report of listed companies in the stock market of Vietnam This study uses a combination of weighting methods, assessing the level of published information of each criterion to measure the level of information disclosure both in terms of quantity and quality. The authors use a combined approach to measure the level of disclosure in the annual report of 289 enterprises in Vietnam. In which, the authors use to test the parameters and non-parametric testing of the level of disclosure of information under the industry and according to Big4 auditing firms. At the same time, in this research, the authors apply the OLS regression and quantile regression model to examine the effect of each factor
\end{abstract}


on the level of information disclosure. Research shows that the level of disclosure in the annual report is $58.57 \%$. The research has identified four factors that affect the level of disclosure: independent audit, enterprise size, profitability, financial leverage. However, there are two factors that do not affect the level of disclosure: the number of members of the board of directors and the Chairman \& General Director. This result will suggest some recommendations to help businesses, agencies to improve the level of information disclosure.

Keywords: Information disclosure, Annual report, Vietnam, OLS regression, Quantile regression

\section{JEL Classifications: M40, M41}

\section{Introduction}

The stock market is an important channel for capital mobilization but to achieve conditions for participation in this capital market, the enterprises must meet several strict conditions. In particular, one of the mandatory conditions that must comply with the regulations on the disclosure of information to the State Securities Commission, investors, shareholders, and other stakeholders.

Information disclosure is influenced by external factors and internal factors of the enterprise. The study of information disclosure (compliance, arbitrary and voluntary) is a topic that attracts the attention of many researchers as well as professionals and policymakers around the world as well as in Vietnam. Studies by (Meek, Roberts, \& Gray, 1995), (Chau \& Gray, 2002) has shown different results when research on information disclosure in different sectors. (Huafang \& Jianguo, 2007), (Fathi, 2013), (Hossain, Perera, \& Rahman, 1995), (Ho \& Wong, 2001) and (Akhtaruddin, Hossain, Hossain, \& Yao, 2009) examined the influence of factor groups such as governance, business size, financial leverage, profitability, auditing and disclosure. These results have similar results, but there are positive or no effect on the level of information disclosure. On the other hand, the regulations at the stock exchanges in each country have different regulations and the business environment is different. Therefore, the study of information disclosure level of listed companies on the stock market in Vietnam still has many meanings. In Vietnam, there have been studies on information disclosure in companies listed on stock exchanges. These studies have initially determined the factors and effects of each factor on the level of information disclosure. The limitations of previous studies were the small sample size (less than 100 enterprises) leading to the low reliability of the research results, the survey samples often eliminated the financial firms. Besides, the researchs is done based on circular 52/2012, while the Ministry of Finance issued Circular $155 / 2015$ have rules change in disclosure. On the other hand, there is no research on measuring factors affecting the level of information disclosure of manufacturing sector and non-manufacturing sector, and compare results obtained. Factors influencing the level of disclosure can have different effects, or have unequal effects in each sector. Since then, the recognition of the solutions to improve the transparency of financial information in each sector may also differ. In particular, previous studies often use the index method to measure the level of information disclosure. In this study, the authors use a combination of weighting methods, assessing the extent of information published by each criterion to measure the 
extent of information disclosure both in terms of quantity and quality of information disclosed. Thus, the expansion of research for enterprises through more fully identify the factors affecting the level of disclosure in order to provide recommendations is really necessary.

The research was carried out in the context that the enterprises implemented information disclosure according to new regulations. At the same time, this study uses a multivariate regression model to analyze the factors affecting the level of disclosure in the annual report. The results of this study are significant for stock market managers who need understand the nature of information disclosure, helps investors evaluate the behavior of listed firms and motivates transparency in the disclosure of information.

\section{Literature Review}

(Meek et al., 1995) studied factors influencing the level of voluntary disclosure and developed a voluntary disclosure catalog based on surveys in the United States, England, and several European countries. The portfolio was built on three aspects: strategic information, financial information and non-financial information. The results showed that the explanatory factors for voluntary disclosure include four factors: company size, geographical area, listing status, and type of industry in which the company operates. When analyzing the type of industry, the author addressed four industries: (1) metalworking, building materials, construction, (2) engineering, (3) consumer goods and services and (4) oil, chemicals, mining. Research results show that the United States has two sectors (metalworking, building materials, construction and oil, chemicals, mining sector) which had higher voluntary disclosure rates than the other two. For the UK, the consumer and service sectors have a much higher level of information disclosure than the other two. This result demonstrates that the level of voluntary disclosure of information differs between business sectors of enterprises.

(Chau \& Gray, 2002) studied the relationship between ownership structure and voluntary disclosure in Hong Kong and Singapore. To build the index disclose information voluntarily, the author based on categories developed by (Meek et al., 1995), and supplementing a number of specific items than the list of measuring the level of voluntary disclosure. In the view of the authors, additional entries are appropriate and they may be published by the enterprise to clearly demonstrate the company's situation to the users of the information on the report. (Huafang \& Jianguo, 2007) has conducted a survey of 559 companies listed in China in 2002. The calculation of the index measuring the level of voluntary disclosure is similar studies above. Then, the author gathered from previous studies to make hypotheses which related to the research model. Variables used in the research model include the ownership of major shareholders, ownership by corporate executives, ownership by the state, ownership by individuals, listing status / ownership of shareholders In addition, independent directors, the separation of the role of the chairman and general manager / director. The results showed that ownership of major shareholders and listing status/ownership of foreign shareholders were two variables which related to the disclosure. The remaining variables have low or no relationship. (Fathi, 2013) conducted a study of 101 companies listed on the 


\section{Mll Macrothink}

International Journal of Accounting and Financial Reporting

ISSN 2162-3082

2019, Vol. 9, No. 2

French stock market for five years from 2004 to 2008 based on 78 indexes. The results indicated that the positive impact of a number of variables such as the size of the board, the involvement of members in board meetings, the presence of the Big 4, and the presence of the Chairman \& General Director. (Hossain et al., 1995) conducted a research on voluntary disclosure of companies in New Zealand in an environment that is attracting investment capital. The results showed that the size of the company, the status of the overseas listing and financial leverage affect the level of voluntary disclosure. In contrast, the proportion of fixed assets, auditing companies are not variables that affect the level of information disclosure. A study by (Ho \& Wong, 2001) in Hong Kong with 98 firms found that the existence of an audit committee was significant and positively related to the voluntary disclosure level, while the proportion of family members (\%) in the board are negatively related to voluntary disclosure. A research by (Akhtaruddin et al., 2009) on corporate governance and voluntary disclosure in Malaysia also showed that the governance factors tested were the size of the board of directors, independent directors in the board of directors, ownership of outside shares, control of the family, and the percentage of members of the audit committee for the total number of board members. The findings suggest a relationship between the size of the board of directors and the voluntary disclosure of information and the proportion of independent directors in the board and voluntary disclosure. However, the level of voluntary disclosure has a negative relationship with regard to family control and the proportion of members of the audit committee to the total number of board members not involved in voluntary disclosure.

In Vietnam, (T. T. H. Nguyễn, 2015) surveyed on the annual report of 106 listed companies listed on HOSE. Research results showed that three factors: (1) enterprise size; (2) type of ownership of foreign elements; (3) Profits which affected the level of voluntary disclosure. (C. P. Nguyễn \& Nguyễn, 2014) used the indicators to measure the level of disclosure and regression models to assess the factors affecting the disclosure level in the financial statements of 99 listed companies on HOSE. In addition, a number of significant factors in previous studies in the world such as state ownership, financial leverage, corporate governance, number of subsidiaries, the market for listing and the complexity of the business do not affect the level of disclosure of research companies.

(Phạm \& Hoàng, 2015) used information disclosure index to measure the level of disclosure and regression models to assess the impact of business characteristics on the disclosure level in the annual report of 100 listed companies on HOSE. Business characteristics included in the study were type of industry, auditing firm, liquidity, profitability, composition of the board of directors, ownership ratio of the board of directors, size of the business, leverage, and foreign ownership. The results of this study showed that the disclosure level of listed companies is not very high $(72.85 \%)$. In addition, factors such as composition of the Board of Directors, the ownership ratio of the Board of Directors, financial leverage, foreign ownership strongly influenced the level of disclosure, other variables did not seem to have any effect.

The study by (Pham \& Do, 2015) assessed the factors influencing voluntary disclosure. Evidence from this study shows that two main factors affecting the level of disclosure are 
foreign ownership and enterprise-size. However, the remaining factors did not affect the level of information disclosure.

\section{Develop Hypotheses}

According to (Adina \& Ion, 2008), there are many factors influencing the level of information disclosure such as level, frequency and method used in disclosure, organizational goals, size of enterprise, listing status, organizational culture and business complexity, the number, type and culture of business owners, the cost of disclosure, the level of convenience for disclosure, level of competition, market share and profitability. Based on the literature review, the authors formulate the following hypotheses:

\subsection{Profitability}

According to representative theory, effective businesses are more likely to be in charge of managing information disclosure (Singhvi \& Desai, 1971), as well as enhancing value of them in the labor market (Barako, 2007). At the same time, high profitability has a positive impact on stock market prices (Inchausti (Inchausti, 1997), 1997). Meanwhile, a study by (Meek et al., 1995) did not show that the effect of profit (after-tax profit/turnover) on voluntary disclosure, similar to that of (T. T. H. Nguyễn, 2015), also showed no correlation between profitability and voluntary disclosure of listed companies which were surveyed on HOSE. Profitable companies usually publish more information. Based on delegation theory, achieve profitability is the result of the efforts of the company manager, so the higher the profit the more they want to disclose information to the owner to create trust, capital investment and It is also a way for managers to improve their self-worth in the labor market. The hypothesis is formulated as follows:

H1: Profitability of enterprises is positively correlated with the level of information disclosure.

\subsection{Enterprise Scale}

Many studies show that firm size affect the same way with the level of voluntary information disclosure. This may be in line with the practice, according to the theory of mandate, that separating roles from owners and direct managers would lead to some kind of cost which is called delegation costs (monitoring, associated costs and other costs) (Jensen \& Meckling, 1976). The owner wants to reduce the cost of commissioning, it should ask the manager to disclose more information; the larger the company, the more information and the higher the information required from the owner. According to (Meek et al., 1995) the size of the business, region/country and international listing status are the three most important explanatory factors for voluntary disclosure. Larger companies are often more complex and have a large scale of ownership so there is a lot of information that needs to be disclosed. This study is also consistent with the study by (Fathi, 2013) in Tunisian where there is a similar effect of firm size and voluntary disclosure. Research by (Ahmad \& Nicholls, 1994) suggested that large-scale enterprises have the resources and expertise needed to make better quality annual reports and thus they often publish more information. Research by (T. T. H. 


\section{MInstitute Macrothink}

International Journal of Accounting and Financial Reporting

ISSN 2162-3082

Nguyễn, 2015) has shown that the size of enterprises is positively correlated with voluntary disclosure. The hypothesis is formulated as follows:

H2: Enterprise size is positively correlated with the level of information disclosure.

\subsection{Financial Leverage}

The company uses good leverage to show the company's credibility with external creditors. Creditors may request more information disclosures from them for the purpose of supervision or the terms of the agreement. Financial leverage and voluntary disclosure have been studied in many countries, but the results vary. The study by (Meek et al., 1995) showed that there is no significant effect of a debt-to-equity ratio on the voluntary disclosure. According to (Hossain et al., 1995), financial leverage has a significant effect on voluntary disclosure. The results of this study are similar to those of (Akhtaruddin et al., 2009), (Ahmad \& Nicholls, 1994), arguing that firms with high leverage have more information disclosure because of owners debt requirements. (Naser, 1998) found the relationship between financial leverage and information disclosure level. The hypothesis is formulated as follows:

H3: Leverage financial companies have a positive relationship with the level of information disclosure.

\subsection{Independent Auditing}

Although the preparation and presentation of financial statements is the responsibility of the manager, the credibility of the auditing firm can significantly influence the information disclosure. Auditor is an integral part of financial statements of listed companies. Previous empirical studies have suggested that the quality of auditing firms has a positive impact on the level of information disclosure by the firm. Studies by (Ahmad \& Nicholls, 1994), (Vu, 2012), (Đặng, 2016) showed the relationship between the size and prestige of auditing firms and information disclosure.

H4: The independent auditor has a positive relationship with the level of information disclosure.

\subsection{Number of Board Members}

The size of the board member affects the disclosure of information. Research by (Barako, 2007) found a relationship between the size of board members and the level of information disclosure. There are two perspectives in relation to this relationship. The first point is that the size of the board members is small, the sharing of information between members, the processing of information will be easier and faster. However, the second view is that the board has a larger membership, has a broader knowledge base to carry out its advisory role, thus fulfills its role, oversees and advises better and more information disclosure. The hypothesis is formulated as follows:

H5: The number of board members has a positive relationship with the level of information disclosure. 


\subsection{Chairman \& General Director}

According to representative theory, concurrently reduces the control role and increased the ability to negotiate bonus level for senior executives. In addition, concurrent people easily dominate power and perform opportunistic and harmful behaviors for other shareholders. (Jouini, 2013) pointed out that Chairman \& General Director has a negative impact on the level of information disclosure, which tends to hide unfavorable information. However, the research results of (Ho \& Wong, 2001) did not show the separation of the two positions that affect the level of disclosure. According to the theory of mandate, there is always a conflict between the owner and the operator. Chairman of the Board represents the owners, executives representing the operator. Therefore, the separation of the role of the chairman of the board of directors and the chief executive is necessary for the business. Healthy environment, the control is properly implemented which will promote the transparency of information. Today, some large companies also voluntarily separate the roles of these two positions, and publicly announce them to shareholders. The hypothesis is formulated as follows:

H6: The number of board members has a positive relationship with the level of information disclosure.

Based on the research hypothesis, the independent variables were measured according to Table 1, below:

Table 1. Factors affecting the level of information disclosure

\begin{tabular}{|c|c|c|c|}
\hline Cod & Factors & Measurement & Direction of impact \\
\hline ROS & Profitability (ROE) & Ratio of profit after tax / turnover & + \\
\hline SIZE & Size of enterprise & Ln (turnover) & + \\
\hline LEV & Financial leverage & Total Liabilities / Total Assets & - \\
\hline AUDIT & Independent auditing & $\begin{array}{l}\text { Dummy variable: } \\
0 \quad-\quad \text { Independent auditing } \\
\text { company not belonging to Big4; } \\
\text { 1- Independent auditing company } \\
\text { belonging to Big4 }\end{array}$ & + \\
\hline NUMBER & $\begin{array}{l}\text { Number of Board } \\
\text { members }\end{array}$ & Total number of board members & + \\
\hline DUAL & $\begin{array}{l}\text { Chairman \& General } \\
\text { Director }\end{array}$ & $\begin{array}{l}\text { Dummy variable: } \\
0 \text {-No concurrently; } \\
\text { 1- Concurrently }\end{array}$ & - \\
\hline
\end{tabular}

Source: Own editing 


\section{Mll Macrothink}

International Journal of Accounting and Financial Reporting

ISSN 2162-3082

2019, Vol. 9, No. 2

\section{Research Methodology}

According to (Wallace \& Naser, 1995), information disclosure is an abstract concept that is difficult to measure directly. It has no inherent characteristic to determine its intensity or quality. The level of disclosure here does not mean that the level of information disclosure is sufficient, meaning that "level" measurement must be expressed as a measure of overall quality in annual reports. So, measuring the level of information disclosure is a difficult issue because it is important to quantify abstractions into a statistical measure of how information is disclosed that express the attributes of information: (1) demonstrates the credibility of the information; (2) objectivity of the information; (3) timeliness of information; (4) Comprehensive information. The study by (Beattie, McInnes, \& Fearnley, 2004) on the analysis of information in the annual report shows that the most used approaches to semi-objective approaches are broken down into text analysis and index analysis. There are also studies that claim no weight for each item in the list of typical indices such as (Cooke, 1989), (Chau \& Gray, 2002), (Akhtaruddin et al., 2009) and (Hossain et al., 1995). Under this approach, the calculation of "1" for the company when there is a certain information in the annual report and " 0 " if not publish this information in the annual report. Based on the review studies, the authors performed measuring the level of information disclosure in the order as follows:

Step 1: Identify indexes, authors based on Circular 155/2015, consisting of 6 main categories, and 25 major indexes, will be assigned a value of 1 if declared, and 0 if not declared.

Step 2: Determine the weight of each index (qualitative and quantitative aspects, form), according to the following criteria:

\begin{tabular}{lll}
\hline \multirow{2}{*}{ Structure } & Content & Weight \\
\hline \multirow{2}{*}{ Content } & The adequacy & 0.45 \\
\cline { 2 - 3 } & Confidence level & 0.40 \\
\hline \multirow{2}{*}{ Presentation } & Report form & 0.05 \\
\cline { 2 - 3 } & Report structure & 0.05 \\
\cline { 2 - 3 } & Interactivity of the report & 0.05 \\
\hline
\end{tabular}

Step 3: Based on the level of information provided in Step 2, assess the level of information disclosure at the following five levels:

Degree evaluation $(\mathrm{M})$

\begin{tabular}{lllll}
\hline 1 (Poor) & 2 (Average) & 3 (Fair) & 4 (Good) & 5 (Excellent) \\
\hline
\end{tabular}




\section{MlMacrothink}

International Journal of Accounting and Financial Reporting

ISSN 2162-3082

2019, Vol. 9, No. 2

Step 4: Calculate the average level of disclosure in the annual report, the disclosure index is calculated as follows:

$$
D_{\mathrm{j}}=\sum \underset{\mathrm{i}=1}{\mathrm{n}_{\mathrm{i} *} \mathrm{M}_{\mathrm{ij}} / \mathrm{n}_{\mathrm{j} * 5}}
$$

In which:

$\mathrm{DI}_{\mathrm{j}}$ : level of information disclosure in the enterprise's annual report $\mathrm{j}$;

$\mathrm{M}_{\mathrm{ij}}$ : Level of assessment from level 1-5 of index i in the enterprise's annual report $\mathrm{j}$;

$d_{i j}=1$ if the information factor $i$ is published in the enterprise's annual report $j$;

$\mathrm{d}_{\mathrm{ij}}=0$ if the information element $\mathrm{i}$ was not published;

$\mathrm{n}_{\mathrm{j}}$ : number of informational factors that can be declared at enterprise $\mathrm{j}(\mathrm{n} \leq 25)$;

Survey data are listed on HOSE. of the 322 listed firms, 289 enterprises had enough information to carry out this study.

Table 2. Summary table of survey samples

Number of enterprises listed on HOSE in 2016

Reduce the number of companies that do not publish annual reports

Reduced number of companies lack, not enough data

Number of enterprises surveyed
322

12

21

Source: The authors collected for research purposes

The data in the study was to collect data from the annual report in 2016. The data collected after computation of the variable matching research requirements using Microsoft Excel. Finally, data on the calculated variables were stored and processed, tested, and analyzed regressed through the Stata 13 software.

\section{Research Results and Discussion}

\subsection{Research Results}

Statistical data (Table 3) showed that the average level of information disclosure of enterprises was $58.57 \%$, the lowest disclosure level was $28 \%$ and the highest was $100 \%$, the standard deviation was $20.47 \%$. In total surveyed enterprises, enterprises with profitability ratios (ROS) were $11 \%$ and the financial leverage ratio (LEV) were $47 \%$ of the average. The financial statements audited by Big4 auditing firms were 35\%, the number of board members 
in enterprises was 6 persons, the highest was 13 and the lowest was 4 and the enterprises with the Chairman \& General Director accounted for $30 \%$.

Table 3. Statistics describe independent variables

\begin{tabular}{llllll}
\hline Variables & $\begin{array}{l}\text { Number of } \\
\text { observation }\end{array}$ & Mean & $\begin{array}{l}\text { Standard } \\
\text { deviation }\end{array}$ & $\begin{array}{l}\text { Minimum } \\
\text { value }\end{array}$ & $\begin{array}{l}\text { Maximum } \\
\text { value }\end{array}$ \\
\hline DI & 289 & 58.57 & 20.47 & 28 & 100 \\
\hline ROS & 289 & 0.11 & 0.17 & -0.61 & 1.12 \\
\hline SIZE & 289 & 13.87 & 1.51 & 10.21 & 17.90 \\
\hline LEV & 289 & 0.47 & 0.23 & 0.01 & 0.98 \\
\hline AUDIT & 289 & 0.35 & 0.48 & 0 & 1 \\
\hline NUMBER & 289 & 6.18 & 1.64 & 4 & 13 \\
\hline DUAL & 289 & 0.30 & 0.46 & 0 & 1 \\
\hline
\end{tabular}

Source: Data in the annual report from HOSE, authors calculated from Stata 13.0

According to Figure 1, the level of information disclosure in the range of $30 \%-40 \%$ is the highest with 65 enterprises accounting for $22.49 \%$, followed by about $50 \%-60 \%$ with 59 enterprises accounting for $20,42 \%$. Meanwhile, the number of enterprises having the information disclosure level is about $90 \%-100 \%$, only 14 enterprises, accounting for $4.84 \%$. At the same time, there are 9 enterprises which have a low level of disclosure between $20 \%$ $30 \%$, accounting for $3.11 \%$.

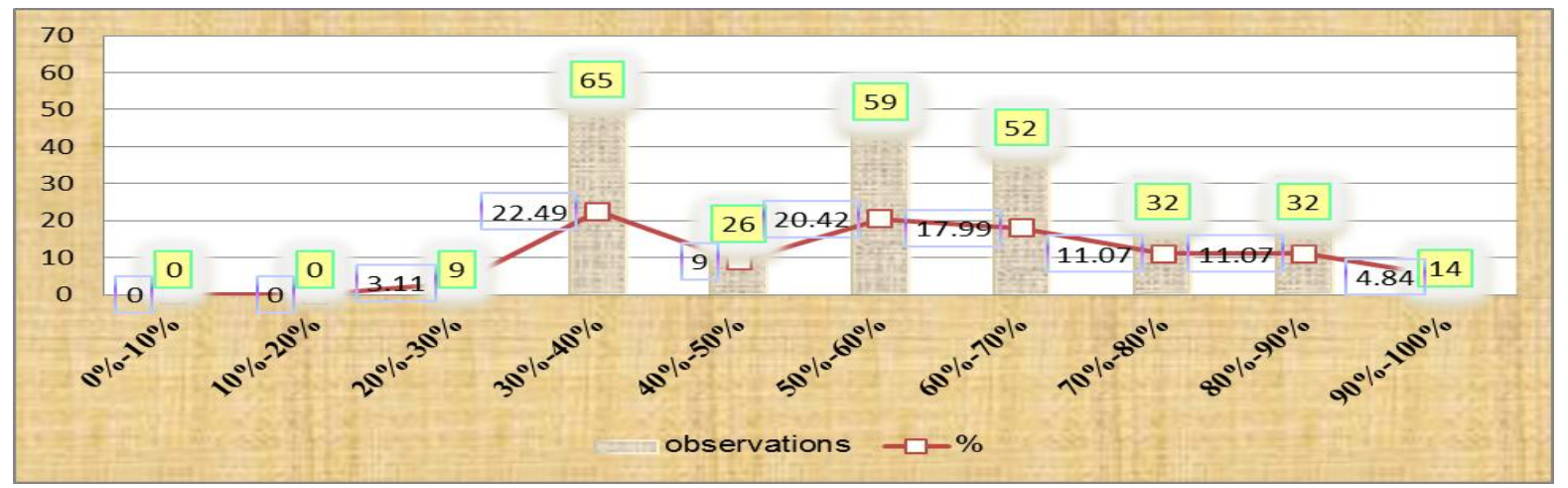

Figure 1. The level of information disclosure in annual reports of enterprises in 2016 Source: Data in the annual report from HOSE, authors calculated from Stata 13.0. 


\section{Mll Macrothink}

International Journal of Accounting and Financial Reporting

ISSN 2162-3082

In terms of information disclosure time (Table 4), the number of enterprises issuing annual reports in accordance with Circular 155/2015 (within 120 days from the end of the annual accounting year) is 265 enterprises, accounting for $91.7 \%$. However, there are 24 enterprises which have the time announced the annual report exceeds the allotted time, accounting for $8.3 \%$ rate. The period from the end of the fiscal year to the end of the fiscal year is $91.05 \%$, accounting for $65.05 \%$.

Table 4. Summarize the time of publication of the annual report

\begin{tabular}{lllc}
\hline $\begin{array}{c}\text { Information } \\
\text { disclosure time }\end{array}$ & $\begin{array}{c}\text { Number of } \\
\text { observations }\end{array}$ & Proportion (\%) & $\begin{array}{c}\text { Rate of information } \\
\text { disclosure (\%) }\end{array}$ \\
\hline Less than 60 & 10 & 3.46 & 55.00 \\
\hline $61-90$ & 67 & 23.18 & 59.30 \\
\hline $91-120$ & 188 & 65.05 & 58.80 \\
\hline $121-150$ & 13 & 4.5 & 56.31 \\
\hline More than 150 & 11 & 3.81 & 56.09 \\
\hline
\end{tabular}

Source: Own editing

Looking at the level of information disclosure in 2016, the results of Table 5 show that the highest disclosure level is in the finance - insurance sector, with an average information disclosure level of $70.38 \%$, while the industry has the lowest information disclosure level of the industry and technology enterprises, with the disclosure rate of $54.83 \%$. By using the ANOVA test, Bartlett's test (Table 5) shows that the variance of the level of information disclosure with Prob> chi $2=0.1209>0.05$ can confirm that there is no difference in the level of information disclosure between sectors.

Table 5. Average days of publication of the annual report of the annual report audited between sectors

\begin{tabular}{|c|c|c|c|c|}
\hline Sector & Average & $\begin{array}{l}\text { Standard } \\
\text { deviation }\end{array}$ & Median & $\begin{array}{l}\text { Number of } \\
\text { observations }\end{array}$ \\
\hline $\begin{array}{l}\text { Real estate and } \\
\text { construction }\end{array}$ & 56.62 & 20.72 & 57.5 & 86 \\
\hline Technology & 54.86 & 22.76 & 49 & 7 \\
\hline
\end{tabular}




\begin{tabular}{lllll}
\hline Industry & 54.83 & 20.30 & 56 & 41 \\
\hline Service & 55.69 & 17.89 & 57.5 & 26 \\
\hline Consumer goods & 64.72 & 17.90 & 69 & 25 \\
\hline Energy & 57.26 & 20.51 & 66 & 23 \\
\hline Agriculture & 65.74 & 16.92 & 66 & 23 \\
\hline Materials & 56.29 & 20.52 & 59 & 34 \\
\hline Finance - insurance & 70.38 & 27.14 & 77 & 16 \\
\hline Medical & 61.38 & 19.06 & 59 & 8 \\
\hline Total & $\mathbf{5 8 . 5 7}$ & $\mathbf{5 8 . 5 7}$ & $\mathbf{5 9}$ & $\mathbf{2 8 9}$ \\
\hline
\end{tabular}

Source: Data in the annual report from HOSE, authors calculated from Stata 13.0.

\begin{tabular}{llllll}
\hline Source & SS & df & MS & F & Prob $>$ F \\
\hline Between groups & 5849.66477 & 9 & 649.9628 & 1.58 & 0.1209 \\
\hline Within groups & 114795.131 & 279 & 411.4521 & & \\
\hline Total & 120644.796 & 288 & 418.9055 & \\
\hline Bartlett's test & for & chi2 $(9)=6.0064$ Prob $>$ chi2 $=0.739$ & \\
\hline
\end{tabular}

Source: Data in the annual report from HOSE, authors calculated from Stata 13.0.

The results of Table 6 show that the level of information disclosure for non-manufacturing enterprises is $62.44 \%$ and the manufacturing sector is $57.21 \%$, so for non-manufacturing enterprises (services, finance - fnsurance, medical, consumer Goods) have higher disclosure levels than manufacturing. Using parametric and nonparametric verification at a 5\% significance level, there is no average difference in the level of information disclosure between manufacturing and non-manufacturing sectors. Similarly, the level of information disclosure to enterprises with the chairman and general director, the level of information disclosure is not much difference. However, for companies audited by Big4, the disclosure level was $70.34 \%$, while the enterprises were not audited by Big4, the disclosure level was $52.34 \%$. The results of the parameter and non-parametric results can be summarized as the 
difference in the level of disclosure to enterprises audited by Big4 with a significance level of $1 \%$.

Table 6. Results of testing the difference in the disclosure level

\begin{tabular}{|c|c|c|c|c|c|c|c|c|}
\hline $\begin{array}{c}\text { Verification } \\
\text { content }\end{array}$ & Classification & $\begin{array}{l}\text { Number of } \\
\text { observations }\end{array}$ & Average & $\begin{array}{c}\text { Number } \\
\text { of degrees } \\
\text { of } \\
\text { freedom }\end{array}$ & $\mathbf{t}$ & Pr & $\mathbf{z}$ & Pr \\
\hline \multirow[t]{2}{*}{ Sector } & $\begin{array}{l}\text { Non- } \\
\text { Manufacturing }\end{array}$ & 75 & 62.44 & \multirow[t]{2}{*}{287} & \multirow[t]{2}{*}{1.911} & \multirow[t]{2}{*}{0.05} & \multirow[t]{2}{*}{1.79} & \multirow{2}{*}{0.072} \\
\hline & Manufacturing & 214 & 57.21 & & & & & \\
\hline \multirow{2}{*}{ Big4 } & Big4 & 189 & 52.34 & \multirow{2}{*}{287} & \multirow{2}{*}{-7.81} & \multirow{2}{*}{0.00} & \multirow{2}{*}{-6.9} & \multirow{2}{*}{0.000} \\
\hline & Non Big4 & 100 & 70.34 & & & & & \\
\hline \multirow{2}{*}{$\begin{array}{l}\text { Chairman } \\
\text { and general } \\
\text { director }\end{array}$} & Big4 & 202 & 58.84 & \multirow{2}{*}{287} & \multirow{2}{*}{0.335} & \multirow{2}{*}{0.73} & \multirow{2}{*}{0.36} & \multirow{2}{*}{0.718} \\
\hline & Non Big4 & 87 & 57.95 & & & & & \\
\hline
\end{tabular}

Source: Data in the annual report from HOSE, authors calculated from Stata 13.0.

Analyzing the correlation coefficient to examine the close relationship between two or more variables, with the absolute value of the correlation coefficient equal 1 , shows a relatively strong correlation. If the correlation coefficient is less than 0.8 , there is a distinct value that exists between the two variables. The correlation coefficient matrix in Table 7, with three variables including SIZE, AUDIT, NUMBER, has a significance level of $<0.05$, and coefficients of correlation between the variables ranged from 0.07 to 0.419 (lower than the condition index of 0.8), showed that 06 independent variables have a relatively linear correlation with the dependent variable (degree of information disclosure) and are less likely to occur multi-collinearity.

Table 7. Correlation matrix

\begin{tabular}{lllllll}
\hline & DI & ROS & SIZE & LEV & AUDIT & NUMBER DUAL \\
\hline DI & 1 & & & & \\
\hline ROS & 0.07 & 1 & & \\
\hline SIZE & $0.3437^{*}$ & $-0.2497^{*}$ & 1 & & \\
\hline
\end{tabular}


LEV $\quad 0.04 \quad-0.2769 * 0.4502 * \quad 1$

\begin{tabular}{llllllll}
\hline AUDIT & $0.4190 *$ & 0.0386 & $0.4154 *$ & $0.1494 *$ & 1 & & \\
\hline NUMBER & $0.1799^{*}$ & 0.0404 & $0.1866 *$ & 0.0376 & $0.1463 *$ & 1 & \\
\hline DUAL & -0.02 & -0.0486 & -0.0394 & 0.0222 & -0.0175 & -0.0765 & 1 \\
\hline
\end{tabular}

* Pearson correlation was statistically significant at $<0.05$.

Source: Data in the annual report from HOSE, authors calculated from Stata 13.0.

The results of linear regression analysis on the relationship between factors affecting the disclosure level (Table 8) show the relationship of four independent variables, in which enterprise size and independent auditing mean statistically significant at $1 \%$ and there are two variables are profitability and financial leverage significant at $10 \%$. The adjusted $\mathrm{R}^{2}$ coefficient is 0.241 , concluding that the linear regression model was constructed in accordance with the data of $24.1 \%$. In other words, the level of information disclosure is influenced by the four factors mentioned above and is influenced by other factors outside the model. When using quartile regression, the number of independent variables significant with the level of information disclosure differed from the OLS regression results, especially those with significant levels of significance at $10 \%$. Based on the data from Table 8 , the VIF of the variable is less than 2 , which proves that the model does not have multi-collinearity. For the variance test, the authors used the Breusch-Pagan test, which gave the coefficient Prob> chi2 $=0.1342$, so it can be concluded that there is no change in variance. model suitable, satisfy the test.

Table 8. Regression model of factors affecting the level of information disclosure

\begin{tabular}{llllll}
\hline & VIF & OLS & P50 & P25 & P75 \\
\hline ROS & 1.14 & $12.04 *$ & 12 & 2.033 & 7.449 \\
\hline SIZE & 1.59 & $3.742^{* * *}$ & $4.654^{* * *}$ & 1.184 & $4.188^{* * *}$ \\
\hline LEV & 1.3 & $-9.855^{*}$ & -12.38 & -2.655 & $-13.55^{* *}$ \\
\hline AUDIT & 1.25 & $13.10^{* * *}$ & $12.34 * * *$ & $22.25 * * *$ & $16.04 * * *$ \\
\hline NUMBER & 1.05 & 1.055 & 0.14 & 1.111 & 0.494 \\
\hline DUAL & 1.01 & 0.448 & -1.07 & 1.101 & 0.6 \\
\hline
\end{tabular}




\begin{tabular}{lllll}
\hline$\_$cons & -1.171 & -4.807 & 11.7 & 10.37 \\
\hline $\mathrm{N}$ & 289 & 289 & 289 & 289 \\
\hline
\end{tabular}
R-sq
0.241

Source: data in the annual report from HOSE, authors calculated from Stata 13.0

When considering the factors affecting the level of information disclosure according to the sectors, for the group of non-manufacturing sectors only factor AUDIT influence positively the level of information disclosure, while for the manufacturing sector the results of the study (Table 9) show the similarity with the whole sample.

Table 9. Model regression factors affect the level of information disclosure

\begin{tabular}{llll}
\hline & All sectors & Manufacturing & Non-manufacturing \\
\hline ROS & $12.04 *$ & $16.86^{* * *}$ & -0.719 \\
\hline SIZE & $3.742^{* * *}$ & $4.122^{* * *}$ & 2.521 \\
\hline LEV & $-9.855^{*}$ & $-10.81^{*}$ & -5.897 \\
\hline AUDIT & $13.10^{* * *}$ & $11.00^{* * *}$ & $19.62 * * *$ \\
\hline NUMBER & 1.055 & 1.271 & -0.0655 \\
\hline DUAL & 0.448 & 1.139 & -0.756 \\
\hline cons & -1.171 & -7.827 & 21.61 \\
\hline N & 289 & 214 & 75 \\
\hline R-sq & 0.241 & 0.218 & 0.315 \\
\hline
\end{tabular}

t statistics in brackets $* \mathrm{p}<0.1, * * \mathrm{p}<0.05, * * * \mathrm{p}<0.01$

Source: Data in the annual report from HOSE, authors calculated from Stata 13.0.

\subsection{Discuss the Research Results}

From the results of the study above, it is possible to give some discussion as follows:

+ The profitability factor has a positive effect on the level of information disclosure with a meaning level of $10 \%$, so the $\mathrm{H} 1$ hypothesis is accepted. The results of this study are 
consistent with previous hypotheses and studies by (Singhvi \& Desai, 1971), (Barako, 2007), (Inchausti, 1997), (T. T. H. Nguyễn, 2015).

+ The enterprise size factor has a positive effect on the level of information disclosure at a $1 \%$ significance level, which is consistent with the $\mathrm{H} 2$ hypothesis and agrees with the results of (Ahmad \& Nicholls, 1994), (Meek et al., 1995), (Fathi, 2013), (T. T. H. Nguyễn, 2015), (Dang, Tran, \& Nguyen, 2018), (Hung, Pham, \& Ha, 2018), (Hoang, Dang, \& Nguyen, 2018), (Ha, Dang, Tran, Van Vu, \& Trung, 2019).

+ Financial leverage factor influences the level of information disclosure at a $10 \%$ significance level, which is contrary to the original H3 hypothesis. Results of this study contrast with the researches by (Hossain et al., 1995), (Akhtaruddin et al., 2009), (Ahmad \& Nicholls, 1994) and (Naser, 1998), however, does not agree with the study of (Meek et al., 1995).

+ The results of the study show that the audit firm variable is consistent with the $\mathrm{H} 2$ hypothesis. This result shows that businesses audited by Big 4 have a higher information disclosure level. Or quality audits of enterprises of the Big 4 is higher and stable than other firms in the industry. This is due to the large categorization that exists in the auditing industry in Vietnam and the quality of audits of non-Big 4 audit firms (mainly domestic auditors) is a concern improving the overall quality of the auditing industry and the audited financial statements. The study results fit with research by (Ahmad \& Nicholls, 1994), (Vu, 2012), (Đặng, 2016).

+ The size of the number of members of the board is not related to the level of information disclosure, the results of this research contrary to the hypothesis H5. This result is in contrast to (Barako, 2007) study finding the relationship between the size of the board member and the level of disclosure. However, the results of this study are consistent with the findings of (Vu, 2012) and (Pham \& Do, 2015), (Hung, Ha, \& Binh, 2018). In Vietnam, the operating regulations of the companies listed on the stock market specified number of board members from 4-11 people. These members are usually major shareholders or representatives of major shareholders. As a result of the regression, the authors found that the number of board members per company is just appropriate for the scale of operation and the characteristics of each enterprise. A small-scale, simple-to-operate company needs less than the number of board members to make quick decisions. Conversely, many members of the board need to take advantage of the diverse experience and capabilities of their members. It means that the companies listed in Vietnam have different scales, so choose the number of members that suits the needs of the company.

+ Chairman and general director factor is not adversely affected to the degree of information disclosure, the results are consistent with the research findings of (Fathi, 2013), (Ho \& Wong, 2001). Hypothesis H6 initially predicted that the level of voluntary disclosure was negatively correlated with the chairman and general director, but the results of the concurrent role of the chairman and general director did not affect the level of disclosure. This result parallels with the research results of (Pham \& Do, 2015), (Hoang, Vu, \& Dang, 2019). 


\section{Mll Macrothink}

International Journal of Accounting and Financial Reporting

ISSN 2162-3082

2019, Vol. 9, No. 2

The study results showed that in Vietnam the non-manufacturing sector with information disclosure level higher than other industries. When considering the factors influencing the level of information disclosure by sector, for non-manufacturing sector there is only independent auditing factor that influences the level of information disclosure, while for the manufacturing sector there are 4 of the 6 factors which affect the level of information disclosure at $1 \%$ and $10 \%$.

\section{Conclusions and Recommendations}

From the results of the study above, the study assessed the impact of factors affecting the level of information disclosure. This article has pointed out four factors that influence the level of information disclosure. There are three factors that are positively correlated: profitability, enterprise size, independent audit, the financial leverage is inversely related to the level of disclosure. Two factors do not affect the level of disclosure is the number of members of the Board of Directors and the chairman of the Board of Directors cum general director. Two factors do not affect the level of information disclosure which are the number of members of the Board of Directors and the chairman and general director.

According to the research results, the author proposes some recommendations to increase the level of disclosure, specifically:

- Independent auditing is one of the factors influencing and significantly affecting the level of information disclosure of enterprise. Therefore, the quality of independent auditing must be further enhanced. The Ministry of Finance, the Accounting - Auditing Association and the Association of Certified Public Accountants need to perform the practice quality control annual audit. Therefore, it is necessary to increase the number of audit firms to be inspected periodically.

- Information users should pay attention to the level of information provided in the annual report on the size of the business, the profitability, the independent auditing company conducting the audit, corporate governance, control risk ... and especially the information on internal transactions, the information of the stakeholders are presented in the annual report.

- The Board of Directors is responsible to the shareholders for the operation of the business. In addition, the board is responsible for monitoring the board's behavior in order to ensure that its actions do not violate the interests of shareholders. Therefore, enterprises need to strengthen their management mechanism, there should be a clear assignment of responsibilities to monitor the disclosure of information in the board members. In the governance structure, there is a need for a clear definition of human resources management to ensure the independence of the board of directors and the board of directors when new independence is ensured to ensure transparency in the disclosure of information.

- In order to encourage listed companies to increase the level of information disclosure, state management agencies should promote seminars for them on impact and benefits of voluntary disclosure of information. Affect as well as benefit to enterprises when enterprises voluntarily publish the information. In addition, there should be mechanisms to encourage companies to voluntarily disclose information, such as an annual award granted by the 
business association or investors to medium-sized businesses which are real, timely and most useful. This solution will help to minimize information distortion between business and user information, making the information provided more transparent and useful.

\section{References}

Adina, P., \& Ion, P. (2008). Aspects regarding corporate mandatory and voluntary disclosure. Annals of the University of Oradea: Economic Science, 3(1), 1407-1411.

Ahmad, K., \& Nicholls, D. (1994). The impact of non-financial company characteristics on mandatory compliance in developing countries: the case of Bangladesh. The International Journal of Accounting, 29(1), 60-77.

Akhtaruddin, M., Hossain, M. A., Hossain, M., \& Yao, L. (2009). Corporate governance and voluntary disclosure in corporate annual reports of Malaysian listed firms. Journal of Applied Management Accounting Research, 7(1), 1-19.

Barako, D. G. (2007). Determinants of voluntary disclosures in Kenyan companies annual reports. African Journal of Business Management, 1(5), 113-128.

Beattie, V., McInnes, B., \& Fearnley, S. (2004). A methodology for analysing and evaluating narratives in annual reports: a comprehensive descriptive profile and metrics for disclosure quality attributes. Paper presented at the Accounting forum.

Chau, G. K., \& Gray, S. J. (2002). Ownership structure and corporate voluntary disclosure in Hong Kong and Singapore. The International Journal of Accounting, 37(2), 247-265.

Cooke, T. E. (1989). Disclosure in the corporate annual reports of Swedish companies. Accounting and Business Research, 19(74), 113-124.

Đặng, N. H. (2016). Các nhân tố ảnh hưởng đến mức độ công bố thông tin kế toán của các doanh nghiệp hoạt động theo mô hình công ty mẹ- công ty con. Kinh tế \& Phát triể, 224(2), 71-79.

Dang, N. H., Tran, M. D., \& Nguyen, T. L. A. (2018). Investigation of the Impact of Financial Information on Stock Prices: The Case of Vietnam. Academy of Accounting and Financial Studies Journal, 22(2), 1-12.

Fathi, J. (2013). The determinants of the quality of financial information disclosed by French listed companies. Mediterranean Journal of Social Sciences, 4(2), 319 - 336.

Ha, T. V., Dang, N. H., Tran, M. D., Van Vu, T. T., \& Trung, Q. (2019). Determinants Influencing Financial Performance of Listed Firms: Quantile Regression Approach. Asian Economic and Financial Review, 9(1), 78-90.

Ho, S. S., \& Wong, K. S. (2001). A study of the relationship between corporate governance structures and the extent of voluntary disclosure 7. Journal of International Accounting, Auditing and Taxation, 10(2), 139-156. 


\section{$\triangle 1$ Macrothink}

International Journal of Accounting and Financial Reporting

ISSN 2162-3082 2019, Vol. 9, No. 2

Hoang, T. V. H., Dang, N. H., \& Nguyen, T. T. P. (2018). The Study of Factors Affecting the Timeliness of Financial Reports: The Experiments on Listed Companies in Vietnam. Asian Economic and Social Society, 8(2), 294-307.

Hoang, T. V. H., Vu, T. T. V., \& Dang, N. H. (2019). Impact of Social Reponsibility Information Disclosure on the Financial Performance of Enterprises in Vietnam. Indian Journal of Finance, 13(1), 20-36.

Hossain, M., Perera, M. H. B., \& Rahman, A. R. (1995). Voluntary disclosure in the annual reports of New Zealand companies. Journal of International Financial Management \& Accounting, 6(1), 69-87.

Huafang, X., \& Jianguo, Y. (2007). Ownership structure, board composition and corporate voluntary disclosure: Evidence from listed companies in China. Managerial Auditing Journal, 22(6), 604-619.

Hung, D. N., Ha, H. T. V., \& Binh, D. T. (2018). Impact of accounting information on financial statements to the stock price of the energy enterprises listed on Vietnam's stock market. International Journal of Energy Economics and Policy, 8(2), 1-6.

Hung, D. N., Pham, C. D., \& Ha, V. T. B. (2018). Effects of Financial Statements Information on Firms' Value: Evidence From Vietnamese Listed Firms. Investment Management and Financial Innovations, 15(4), 210-218.

Inchausti, B. G. (1997). The influence of company characteristics and accounting regulation on information disclosed by Spanish firms. European Accounting Review, 6(1), 45-68.

Jensen, M. C., \& Meckling, W. H. (1976). Theory of the firm: Managerial behavior, agency costs and ownership structure. Journal of Financial Economics, 3(4), 305-360.

Jouini, F. (2013). Corporate governance and the level of financial disclosure by Tunisian firm. Journal of Business Studies Quarterly, 4(3), 95.

Meek, G. K., Roberts, C. B., \& Gray, S. J. (1995). Factors influencing voluntary annual report disclosures by US, UK and continental European multinational corporations. Journal of International Business Studies, 26(3), 555-572.

Naser, K. (1998). Comprehensiveness of disclosure of non-financial companies: Listed on the Amman financial market. International Journal of Commerce and Management, 8(1), 88-119.

Nguyễn, C. P., \& Nguyễn, T. T. P. (2014). Các yếu tố ảnh hưởng đến mức độ công bố thông tin tài chính của công ty niêm yết. Phát Triển Kinh Tế, 278(1), 15-33.

Nguyễn, T. T. H. (2015). Các nhân tố ảnh hưởng đến mức độ công bố thông tin tự nguyện của các doanh nghiệp niêm yết trên HOSE. Phát Triển Kinh Tế, 26(11), 99-115.

Pham, D. H., \& Do, T. H. L. (2015). Factors Influencing the Voluntary Disclosure of Vietnamese Listed Companies. Journal of Modern Accounting and Auditing, 11(12), 656-676. 


\section{Macrothink}

International Journal of Accounting and Financial Reporting

ISSN 2162-3082 2019, Vol. 9, No. 2

Phạm, N. T., \& Hoàng, T. T. H. (2015). Ảnh hưởng của đặc điểm doanh nghiệp đến mức độ công bố thông tin trên thị trường chứng khoán Thành phố Hồ Chí Minh. Phát Triển Kinh Té, 26(4), 87-103.

Singhvi, S. S., \& Desai, H. B. (1971). An empirical analysis of the quality of corporate financial disclosure. The Accounting Review, 46(1), 129-138.

Vu, K. B. A. H. (2012). Determinants of voluntary disclosure for Vietnamese listed firms. Curtin University.

Wallace, R. O., \& Naser, K. (1995). Firm-specific determinants of the comprehensiveness of mandatory disclosure in the corporate annual reports of firms listed on the stock exchange of Hong Kong. Journal of Accounting and Public Policy, 14(4), 311-368.

\section{Copyright Disclaimer}

Copyright for this article is retained by the author(s), with first publication rights granted to the journal.

This is an open-access article distributed under the terms and conditions of the Creative Commons Attribution license (http://creativecommons.org/licenses/by/4.0/) 